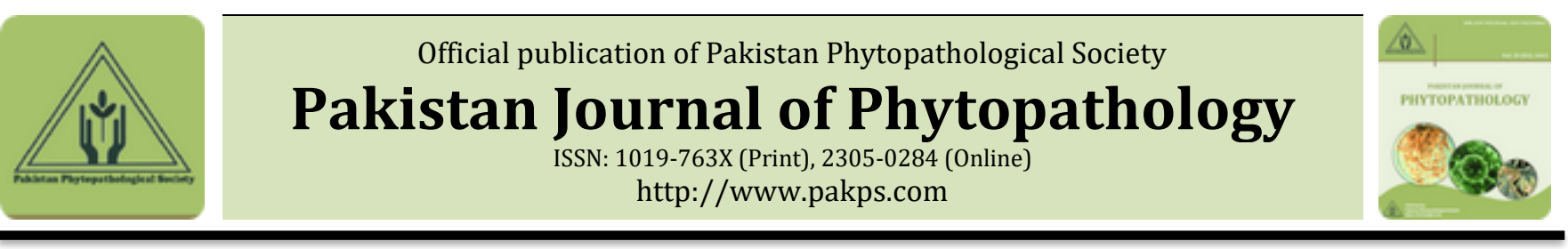

\title{
COMPARATIVE EFFICACY OF DIFFERENT ANTIBIOTICS, FUNGICIDES AND BOTANICAL EXTRACT FOR THE CONTROL OF CITRUS CANKER OF KINNOW MANDARIN
}

\author{
aMalik A. Rehman*, aShafqat Ali, aMuhammad N. Khan, bSalman Ahmad, bMuhammad A. Ali \\ ${ }^{a}$ Citrus Research Institute Sargodha, Pakistan. \\ ${ }^{b}$ College of Agriculture, University of Sargodha, Sargodha, Pakistan.
}

\begin{abstract}
A B S T R A C T
Citrus canker is one of the most devastating disease of citrus crop. It is a worldwide disease, caused by bacterium Xanthomonas axonopodis pv. citri. Citrus canker incidence has been observed on most of the citrus varieties. Severe infection of the bacterium produces a variety of effects including defoliation, dieback, severely blemished fruit, reduced fruit quality and premature fruit drop. Present study was conducted at Citrus Research Institute, Sargodha during the years 2016-18 on ten years old kinnow plants. There were ten treatments including control with four replications. Spray was done four times in a year during the months of March, April, August, and September. The efficacy of different treatments was compared to control the disease incidence on leaves and fruits. It was concluded that Bordeaux mixture was the most suitable chemical to control the canker on kinnow plant and it also improved the quality of fruit in terms of fruit weight, fruit size and juice weight. Besides, copper hydroxide and onion extract were also found efficacious to control the disease. In future, these chemicals and plant extracts could be used in different combinations to control canker on different citrus varieties.
\end{abstract}

Keywords: Fungicides; Botanical extracts; Citrus canker; Xanthomonas axonopodis pv. citri; kinnow.

\section{INTRODUCTION}

It is an established fact that Pakistan fruit sector is dominated by citrus both in area and production. The province of Punjab contributes $95 \%$ in the entire citrus activity. It is grown over an area of 177.22 thousand hectares with the production of 2116.47 thousand tons. (Crop reporting services $\mathrm{Pb}$. 2016-17). The overall scenario of kinnow export in the background of stringent measures on the quality characters has gone depressive. Among the most disturbing diseases citrus canker disease has emerged as major hurdle in the smooth flow of our kinnow in the supply chain of export. The disease from nursery to fruit harvest has serious repercussions not only on the healthy and disease free flushing of citrus orchard but also giving a serious set-

\section{Submitted: July 14, 2020}

Revised: December 15, 2020

Accepted for Publication: December 16, 2020

* Corresponding Author:

Email: arroufkhan@gmail.com

(C) 2017 Pak. J. Phytopathol. All rights reserved. back to citrus export. In the background of this situation a well-conceived research trial has been initiated comparing the efficacy of different fungicide/ bactericides and botanical extract.

Due to the disturbing factor of quality attributed to some of serious diseases of pathological origin fruit is badly blemished and is rejected by the export based supply chain. The major blemish causing diseases are citrus scab, melanose and citrus canker, however the citrus canker caused by the bacterium Xanthomonas axonopodis pv. citri is probably the worst enemy to the citrus plantations (Sahiet al., 2007). It is a common and widely distributed disease of Indo-Pak Sub-Continent (Ari fetal, 1964) and most commonly occurs in the citrus growing areas of the Punjab on most of the commercially important citrus cultivars (Hafiz and Sattar, 1952; Kuhara, 1978; Garnsey et al, 1979; Atiq et al, 2007). The disease is found in South East Asia, Japan, China, India, Pakistan and the Island of Indian Ocean (Das, 2008). The incidence of canker is very common on nursery plants as well as in the orchards. Symptoms are developed on all above ground parts of the plants that are leaves, twigs 
and fruit. Raised, necrotic corky lesions are developed on diseased parts of the plant. In case of severe infection of the disease, defoliation, dieback, deformation of fruit and premature fruit drop may occur (Rossetti, 1977; Civerolo, 1981; Chand and Pal, 1982; Stall Seymour, 1983). Fluctuation of disease correlates with rain fall and temperature (Graham et al., 1989). Its severity increases if rainfall occurs during new sprouting and early fruit development stages (Saleem and Tariq, 1992). Intensity of infection varies with the species and varieties (Folico de Alcoraz, 1986).

Various workers reported the control of citrus canker through chemicals. Kishun and Chand (1987) reported control of canker by four sprays of copper oxychloride (500ppm) after two prunings. Similarly, Balaraman and Pursotman (1981) found that six sprays of streptomycin sulfate (100ppm) along with two prunings reduced the canker in acid lime. Chakravarti and Hedge (1970) found that agrimycin was effective against the disease. Streptomycin in combination with bordeaux mixture had also been found effective in controlling the disease (Bhupendra et al., 2017; Karishna and Noma, 1998). Other chemicals found effective are mixture of sodium arsenate and copper sulfate and thiram (Beniwal and Chaubey, 1976). Rehman et al. (2006) studied that streptomycin sulfate, trimiltox and copsykill were effective for the control of citrus canker. Similarly many researchers reported control of citrus canker by using antibiotics and plant extracts. Tahir et al. (2016) found streptomycin sulfate alone and in combination with Allium sativum and Azadirachta indica was very effective for the control of citrus canker. Islam et al. (2014) reported antibiotic chloramphenicol and plant extracts of Allium sativum and Syzgium cumini could be implicated for the disease citrus canker. Similarly, Yesmin et al. (2017) applied different fungicides and plant extracts for the control of canker of citrus (Citrus limon). They concluded that the fungicide Rovral 50 WP and neem leaf extract were found most effective in controlling the disease.

Extensive and repeated use of pesticides has developed resistance in plant pathogenic bacteria (Sundin et al, 1994; Calrke et al., 1997; William and Heymann, 1998; White et al., 2002). In order to avoid the dangerous effect of synthetic pesticides on the environment, an alternative approach for the control of plant pathogenic organisms is very necessary (Hostettmann and Wolfender, 1997). Mahajan and Das (2003) reported plants and microbes as potential source of pesticide for future use. Many researchers reported plant byproducts as anti-microbes against several plant pathogenic bacteria and fungi (Dorman and Deans, 2000; Parameswari and Latha, 2001; Rath et al, 2004; Britto and Santhil, 2001; Bylka et al, 2004; Shimpi and Bendre, 2005; Kilani, 2006).

The chief objectives of the study was to develop effective pattern spray program in a cyclic manner based on an integrating approach to increase the overall impact on canker disease control strategy. The study conducted in Citrus Research Institute, Sargodha was expected to have very good and encouraging results to manage the notorious disease of canker. Use of plant extract for the control of disease is the step towards organic farming. Similarly, there will be no residual effects of chemicals in the kinnow fruit being exported. The bordeaux mixture and onion extract are easily available, economical and have long lasting effects to control citrus canker.

\section{MATERIAL AND METHODS}

Three types of the spray materials were used in this study that were plant extract, antibiotics and fungicides. An aqueous crude extract was prepared by grinding Allium cepa $200 \mathrm{~g}$ for fresh and $100 \mathrm{~g}$ for dry samples. Material was soaked in $100 \mathrm{ml}$ of sterilized distilled water and then passed through sieve. The supernatant was used for the spray against the citrus canker. The solutions of other chemicals and antibiotics were prepared by mixing the definite amount with tap water (Table 1). The ten treatments were: T1 (copper hydroxide, $3 \mathrm{~g} / \mathrm{L}$ of water), T2 (Bacillius spp., $3 \mathrm{~g} / \mathrm{L}$ of water), T3 (streptomycin+ copper oxychloride, $1+3 \mathrm{~g} / \mathrm{L}$ of water), T4 (Bordeaux mixture, 1\% (1:1::100)), T5 (validamycin, $1 \mathrm{~mL} / \mathrm{L}$ of water), T6 (kasugamycin + copper oxychloride, $3 \mathrm{~mL}+3 \mathrm{~g} / \mathrm{L}$ of water), $\mathrm{T} 7$ (copper oxychloride + validamycin, $3 \mathrm{~g}+1 \mathrm{~mL} / \mathrm{L}$ of water) T8 (onion extract, 10 $\mathrm{mL} / \mathrm{L}$ of water), T9 (sulphur, $2.5 \mathrm{~g} / \mathrm{L}$ of water), T10 (control). All the chemicals, antibiotics and plant extract were sprayed with knapsack hand sprayer (20 L capacity) four times during the year in the months of March, April, July and August. Each treatment was sprayed on four plants. Control plants were left without any spray. The trial was conducted during the years 2016-18 on the 10 years old kinnow orchard of Citrus Research Institute, Sargodha (Punjab, Pakistan) showing citrus canker symptoms. Treatments were arranged in a completely randomized design with four replications. There was one plant in each replication and total numbers of plants were 40. Data were recorded after 20 days of last application from the leaves (30 leaves per plant which were taken randomly) and fruits and assessed for disease incidence (\%age of canker infected leaf and fruit). 
Table 1. Composition of different treatments with dosage rates

\begin{tabular}{llll}
\hline Treatments & Name of chemicals & Dose & Mode of action \\
\hline T1 & Copper hydroxide & $3 \mathrm{~g} / \mathrm{L}$ of water & Protectant \\
T2 & Bacillus spp. & $3 \mathrm{~g} / \mathrm{L}$ of water & Systemic \\
T3 & Streptomycin+ copper oxychloride & $1+3 \mathrm{~g} / \mathrm{L}$ of water & Systemic + Protectant \\
T4 & Bordeaux mixture & $1 \%(1: 1:: 100)$ & Protectant \\
T5 & Validamycin & $1 \mathrm{~mL} / \mathrm{L}$ of water & Systemic \\
T6 & Kasugamycin + copper oxychloride & $3 \mathrm{~mL}+3 \mathrm{~g} / \mathrm{L}$ of water & Systemic + Protectant \\
T7 & Copper oxychloride + validamycin & $3 \mathrm{~g}+1 \mathrm{~mL} / \mathrm{L}$ of water & Systemic + Protectant \\
T8 & Onion extract & $10 \mathrm{~mL} / \mathrm{L}$ of water & Protectant \\
T9 & Sulphur & $2.5 \mathrm{~g} / \mathrm{L}$ of water & Protectant \\
T10 & Control & No treatment & N/A \\
\hline
\end{tabular}

How the data was recorded, statistical analysis were were recorded for the parameters like fruit weight, performed, this information is missing here. fruit size, peel thickness, juice weight, peel weight, Similarly, for the study of effect of citrus canker on TSS and acidity. The disease incidence $\%$ was the physico-chemical characters of the fruit, the data calculated as:

$$
\text { Disease incidence }(\%)=\frac{\text { No. of infected leaves }}{\text { No. of leaves sampled }} \mathrm{X} 100
$$

Total soluble solids were measured with digital different chemicals significantly inhibited the attack of refractometer (ATAGO, RX5000, USA) replacing one or two drops of juice on the prism of refractometer.

\section{STATISTICAL ANALYSIS}

The raw data was processed in MS Excel and subjected to statistical analysis by STATISTIX software version 8.1 using RCBD layout to get the ANOVA. The mean values were compared by least significance difference (LSD) test and were considered to differ significantly at $\alpha \leq 0.05$.

\section{RESULT AND DISCUSSION}

Control of citrus canker on leaves: Leaves are the prime organ of the plant involved in major plant functions e.g. photosynthesis, and respiration. Disease incidence on leaves directly affects the plant growth either vegetative growth or fruit production and ultimately leads to financial loss. In this experiment it was studied that use of

\section{citrus canker.}

During the year 2016, it was concluded that T4 was the excellent combination to control canker on leaves and 5.25 per 100 leaves were affected where T4 (Bordeaux mixture) was sprayed. T1 (copper hydroxide) and T8 (onion extract) also decreased the incidence of disease as compared to other treatments and 6 and 7.25 leaves out of hundred were affected respectively. In T2 (Bacillius spp.), T3 (streptomycin+ copper oxychloride), T5 (validamycin), T6 (kasugamycin + copper oxychloride), T7 (copper oxychloride + validamycin) and T9 (sulphur), number of affected leaves were 14.75, 6.5, 14.75, 4.75, 11.25 and 12.25 per hundred leaves (Figure 1 and Table 2). Control treatment showed maximum number of affected leaves that were 29.25 out of hundred leaves.

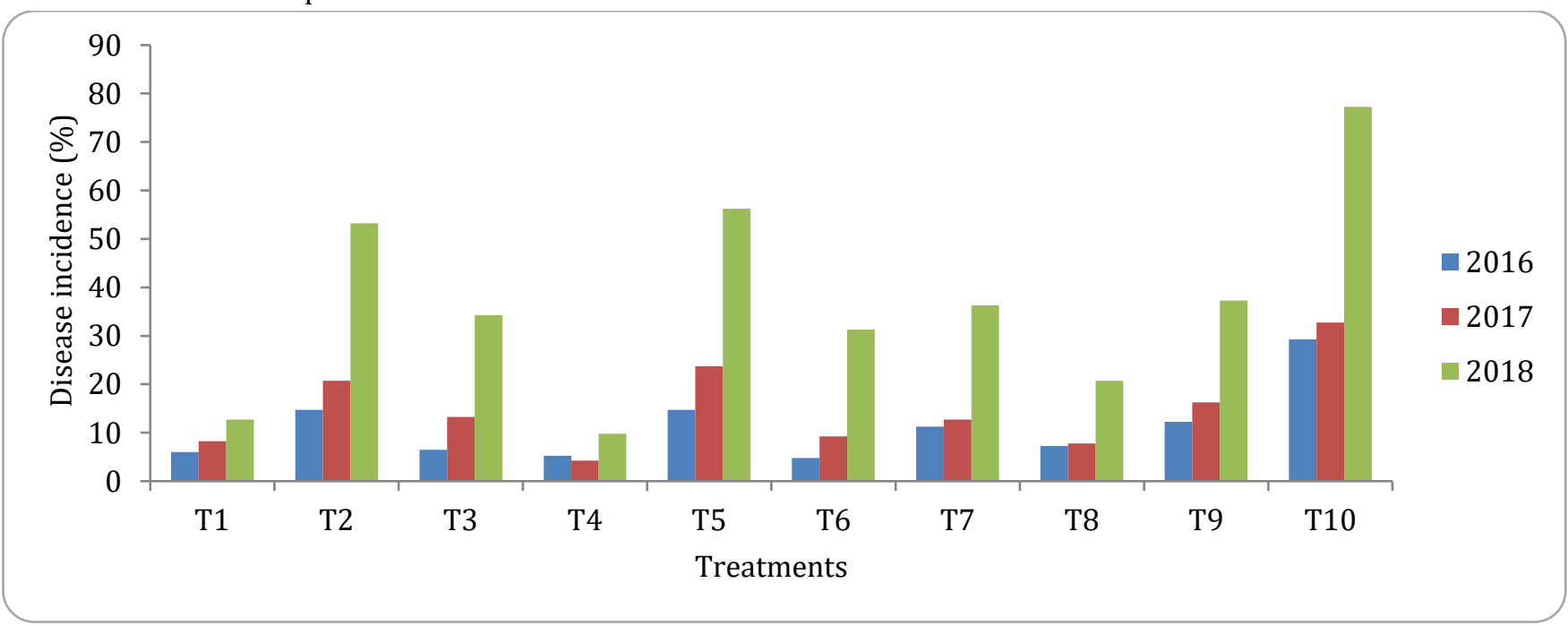

Figure 1. Effect of different treatments to control citrus canker on leaves during the year 2016-2018 
Table 2. Summary of disease incidence on leaves during the years 2016-2018

\begin{tabular}{llll}
\hline Treatments & Disease incidence (\%) 2016 & Disease incidence (\%) 2017 & Disease incidence (\%) 2018 \\
\hline T1 & $6 \mathrm{D}$ & $8.25 \mathrm{E}$ & $12.75 \mathrm{E}$ \\
T2 & $14.75 \mathrm{~B}$ & $20.75 \mathrm{~B}$ & $53.25 \mathrm{~B}$ \\
T3 & $6.5 \mathrm{D}$ & $13.23 \mathrm{C}$ & $34.25 \mathrm{C}$ \\
T4 & $5.25 \mathrm{D}$ & $4.25 \mathrm{~F}$ & $9.75 \mathrm{E}$ \\
T5 & $14.75 \mathrm{~B}$ & $23.75 \mathrm{~B}$ & $56.25 \mathrm{~B}$ \\
T6 & $9.75 \mathrm{D}$ & $9.25 \mathrm{DE}$ & $31.25 \mathrm{C}$ \\
T7 & $11.25 \mathrm{C}$ & $12.75 \mathrm{CD}$ & $36.25 \mathrm{C}$ \\
T8 & $7.25 \mathrm{D}$ & $7.75 \mathrm{EF}$ & $20.75 \mathrm{D}$ \\
T9 & $12.25 \mathrm{BC}$ & $16.25 \mathrm{C}$ & $37.25 \mathrm{C}$ \\
T10 & $29.25 \mathrm{~A}$ & $32.75 \mathrm{~A}$ & $77.25 \mathrm{AS}$ \\
\hline
\end{tabular}

From data of 2017, T4 (Bordeaux mixture) was found very useful to control canker on leaves and minimum 4.25 out of hundred leaves were affected where T4 was sprayed. T1 (copper hydroxide) and T8 (onion extract) also reduced disease effect compared to other treatments as 8.25 and 7.75 leaves per hundred were affected, respectively. All other treatments could not produce satisfactory results and canker effect was increased gradually. In T2 (Bacillius spp.), T3 (streptomycin+ copper oxychloride), T5 (validamycin), T6 (kasugamycin + copper oxychloride), T7 (copper oxychloride + validamycin) and T9 (sulphur) plants, numbers of affected leaves were 20.75, 13.23, 23.75, $9.25,12.75$ and 16.25 per hundred leaves, respectively. Control treatment plants had maximum number of affected leaves 32.75 out of hundred leaves (Figure 1). In $3^{\text {rd }}$ year it was concluded that $\mathrm{T} 4$ had optimum results and minimum number of leaves were affected where T4 was sprayed as 5.75 leaves were affected per 100 leaves. $\mathrm{T} 1$ and T8were also effective to control the disease as 12.75 and 20.75 leaves were affected, respectively. T2, T3, T5, T6, T7, and T9 showed number of affected leaves $53.25,34.25,56.25,31.25,36.25$ and 37.25 respectively (see Figure 1). Control treatment had maximum number of affected leaves i.e. 77.25 out of hundred leaves.
Control of citrus canker on fruit: Citrus canker affects the fruit of citrus and significantly reduces fruit yield and fruit quality. Scientists had applied many control measures to control this loss. In this study, 10 different treatments were applied and finally got the following results after three years of applications.

This study demonstrated that $\mathrm{T} 4$ proved the excellent combination to control canker on fruit during the year 2016 and 0.5 per 100 fruit was affected where T4 was sprayed. T1 and T8 also reduced its effect compared to other treatments as 1 and 2.8 per 100 fruits were affected, respectively. In T2, T3, T5, T6, T7 and T9 number of effected fruits per hundred were 3.75, 2.5, 4, 2.9, 3.5, and 3.8, respectively (Figure 2). Control treatment had maximum number of affected fruits 6.5 out of hundred fruits.

In the second year results showed that $\mathrm{T} 4$ was the best to control canker on fruit, and all the fruits were found free of canker. T1 and T8 also showed positive effects and reduced the disease impact up to a certain limit as 0.5 and 0.25 per hundred fruits were damaged. In T2, T3, T5, T6, T7 and T9 number of affected fruits were 2.25 , $1.25,1.75,0.5,1.75$ and 2.25 , respectively (Table-3). Control treatment had maximum number of affected fruits that were 5.25 out of hundred (see Figure 2).

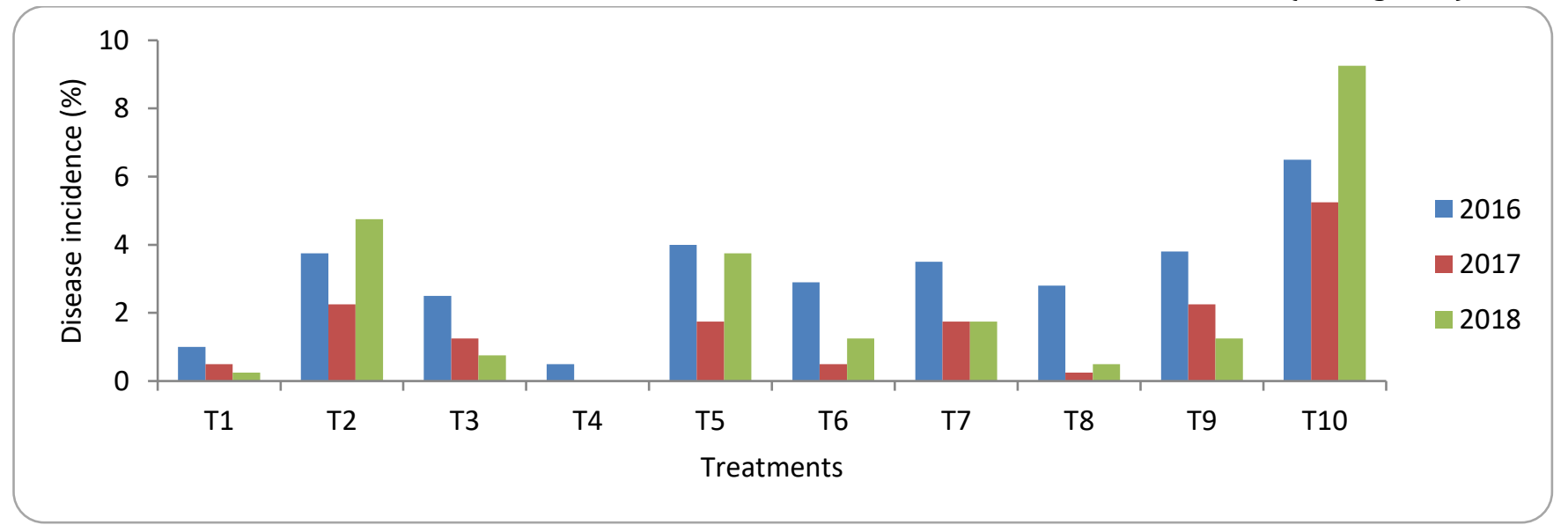

Figure 2. Comparative efficacy of different treatments to control citrus canker on fruit during the year 2016-2018 
Table 3. Comparison of efficacy of different treatments to control the disease on fruit during the years 2016-2018

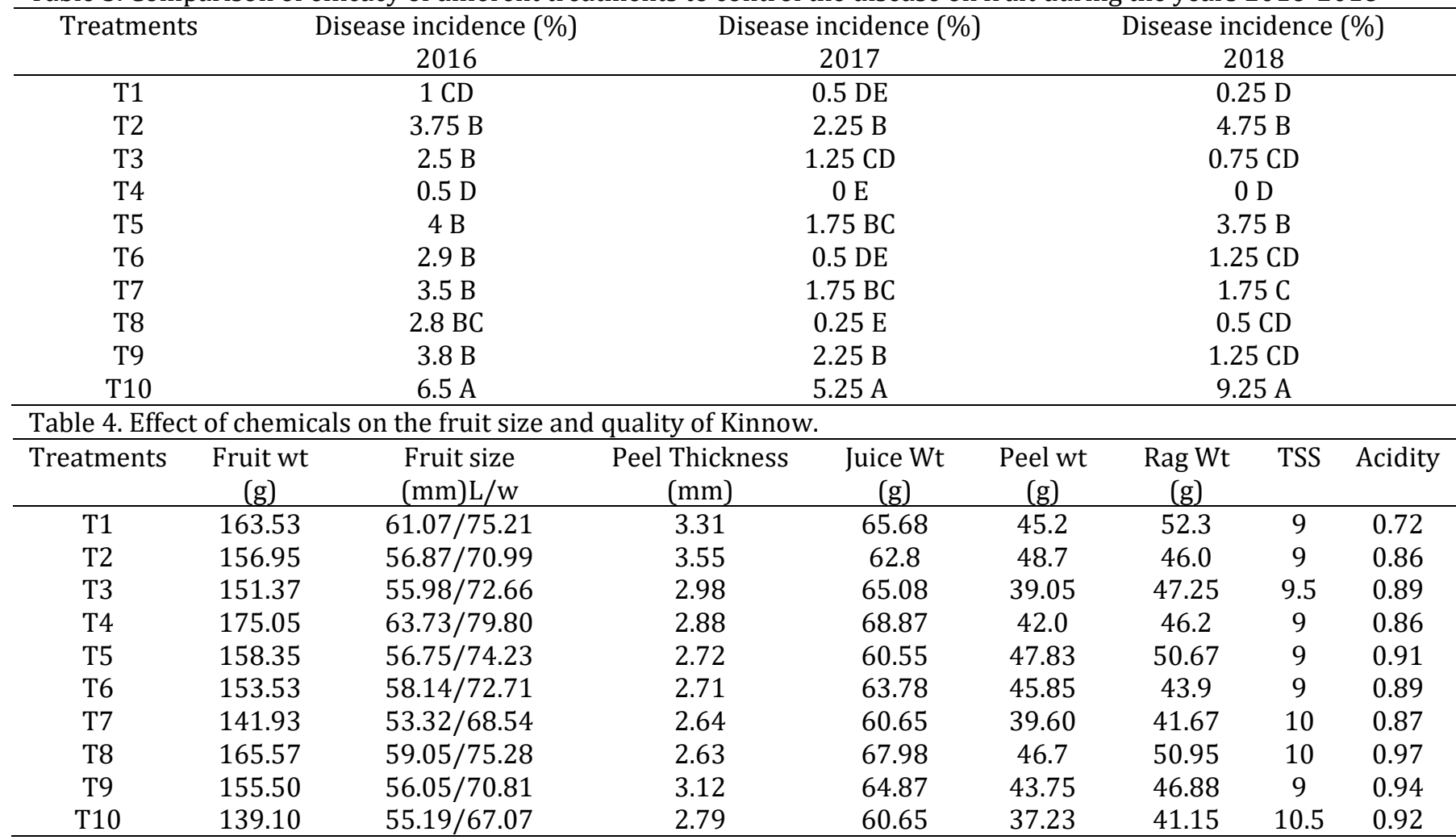

In the final year, T4 showed the best results to control canker on fruit and no fruit was affected with canker. T1 and $\mathrm{T} 8$ also reduced its affect as compared to other treatments where 0.25 and 0.5 fruits were affected, respectively. In T2, T3, T5, T6, T7 and $\mathrm{T} 9$, the affected fruits were $4.75,0.75,3.75,1.25,1.75$ and 1.25 per hundred fruits, respectively (see Figure 2). Control treatment had maximum number of affected fruits 9.25 out of hundred fruits.

Present results are in line with the findings of Khan et al. (2018) who found remarkable control of citrus canker by copper-based chemicals. Similarly, in one of the previous study, streptomycin sulfate and $A$. cepa extract significantly reduced citrus canker (Atiq et al., 2018). Such findings are comparable with the results of Tahir et al. 2016 who used ten leaves extract and found A. cepa effective in controlling citrus canker.

Effect of treatments on the physico-chemical parameters of kinnow: All the treatments affected the fruit quality significantly in different aspects but T4 showed good results in all parameters. Fruit parameters measured were fruit weight, fruit juice, fruit size, peel thickness, juice weight, peel weight, Rag weight, TSS and acidity. In different treatments different results were obtained but T4 (Bordeaux mixture) showed excellent results and maximum fruit weight, fruit size, and juice weight was obtained in $\mathrm{T} 4$ and it was $175.05 \mathrm{~g}$, $63.73 / 79.80 \mathrm{~mm}(\mathrm{~L} / \mathrm{W}$ ) and $68.87 \mathrm{~g}$, respectively and minimum was in control treatment that was $139.10 \mathrm{~g}$, $55.19 / 67.07 \mathrm{~mm}(\mathrm{~L} / \mathrm{W})$ and $60.65 \mathrm{~g}$, respectively. Peel thickness, peel weight, TSS and acidity was of standard value that is required in excellent quality fruit and it was $2.88 \mathrm{~mm}, 42.0 \mathrm{~g}, 9$ and 0.86 for T4. Besides T4, T1 and T8 also had shown good results.

\section{CONCLUSION}

This study was carried out to find the comparative efficacy of different antibiotics, fungicides and botanical extracts for the control of citrus canker of kinnow. This experiment was carried out at Citrus Research Institute, Sargodha during the years 2016-18 on ten years old kinnow plants. There were ten treatments including control with four replications hence total number of plants were forty. Spray was done four times in a year during the months of March, April, August, and September and data were collected after each spray. The data were analyzed and it was concluded that bordeaux mixture (T4) was the most suitable to control the canker on leaves and fruit. Copper hydroxide and onion extract were other treatments that effectively controlled disease incidence on leaves and fruit. The effect of chemicals on 
the quality of fruit was investigated and it was found that bordeaux mixture significantly improved the quality of fruit including fruit weight, fruit size and juice weight. After three years of study, it was concluded after bordeaux mixture copper hydroxide and onion extract could be potential treatments to control citrus canker on kinnow if their doses and application frequency are optimized. These results are very encouraging as these treatments have no residual effects, hence it will open a door towards organic farming. Further studies are required to evaluate effects of these chemicals to control citrus canker on different citrus varieties

\section{REFERENCE}

Ali, M. R., M. F. Hasan, R. S. Lia, A. Akhter, M. S. E. Sumi, M. F. Hossain, M. Islam, M. Khalekuzzaman and B. Sikdar. 2017. Isolation and characterization of a canker disease causing pathogen from Citrus aurantifolia and evaluation of its biological control measure. Journal of Entomology and Zoology Studies, 5: 1526-1532.

Anonymous. 2017. Crop reporting services. Govt of Punjab, Pakistan.

Arif, A.G., M. Akhtar and M. Ibrahim. 1964. Citrus disease and their control. Punjab Fruit Journal, 26: 2736970.

Atiq, M., M. A. Khan and S. Sahi. 2007. Screening of citrus germplasm for the sources of resistance against canker disease caused by Xanthomonas axonopodis pv. Citri. Pakistan Journal of Phytopathology, 19: 222-226.

Atiq, M., M. Aslam Khan, S. Talib Sahi, R. Ahmad, M. Younas, M. Shafiq and Y. Ali. 2018. Appraisal of plant extracts and streptomycin sulfate against citrus canker disease. Archives of Phytopathology and Plant Protection, 51: 824-833.

Balaraman, K. And R. Purushotman. 1981. Control of citrus canker on acid lime. South Indian Horticulture, 29: 175-177.

Beniwal, S. And B. SPS. 1976. Thiram, a fungicide effective against Xanthomonas citri (hasse) dowson. Pesticides, 10:31-36.

Britto, S. John, and S. Senthilkumar. 2001. Antibacterial activity of Solanum incanum L. leaf extracts. Asian Journal of Microbiology, Biotechnology \& Environmental Sciences 3: 65-66.

Bylka, W., I. Matlawska and N. Pilewski. 2004. Natural flavonoids as antimicrobial agents. Jana, 7: 24-31.
Chakravarti, B. And S. Hegde. 1970. Studies on citrus canker in Rajasthan. III. Control of citrus canker by antibiotics and chemicals. Punjab Horticultural Journal, 10: 161-165.

Chand, J. And V. Pal. 1982. Citrus canker in India and its management. Problems of citrus diseases in India/edited by SP Raychaudhuri, YS Ahlawat. Surabhi printers and publishers, New Delhi. PP. 2126.

Civerolo, E. L. "Citrus bacterial canker disease: An overview." Proceedings of the International Society of Citriculture/[International Citrus Congress, November 9-12, 1981, Tokyo, Japan; K. Matsumoto, editor]. Shimizu, Japan: International Society of Citriculture, 1982-1983., 1982.

Das, A. 2003. Citrus canker-A review. Journal of Applied Horticulture, 5: 52-60.

Dorman, H. D. And S. G. Deans. 2000. Antimicrobial agents from plants: antibacterial activity of plant volatile oils. Journal of applied microbiology, 88: 308-316.

Folico - de - Olaroz, L. 1986. Multiplication of Xanthomonas competitive.Citri in leaf tissue of different citrus species. Fitopatologia, 21: 52-60.

Garnsey, S. M., E. L. Clichorme, J. W. Field, C. P. Seymour, J. T. Griffiths. 1979. Citrus Canker. Citrus Indus, 60: 5-6.

Graham, J., T. Gottwald, E. Civerolo and R. Mcguire. 1989. Population dynamics and survival of Xanthomonas campestris in soil in citrus nurseries in Maryland and Argentina. Plant Disease, 43: 423-427.

Hostettmann, Kurt, and Jean-Luc Wolfender. 1997. The search for biologically active secondary metabolites. Pesticide science 51: 471-482.

Khan, W. A., M. Atiq, S. T. Sahi, A. A. Khan, S. Ali, M. Younas, Y. Ali, M. R. Bashir and M. Sajid. 2018. Induction of Resistance against Citrus Canker through Chemicals and Plant Activators. Advances in Zoology and Botany, 6: 26-30.

Kilani, A. 2006. Antibacterial assessment of whole stem bark of Vitex doniana against some enterobactriaceae. African Journal of Biotechnology, 5.

Kishun, R. and L. Chand. 1987. Studies on germplasm resistance and chemical control of citrus canker. Indian Journal of Horticulture, 44:126-32.

Krishna, Ashok, and A. G. Nema. 1983. Evaluation of chemicals for the control of citrus canker. Indian 
Phytopathology, 36: 348-50.

Mahajan, A. And S. Das. 2003. Plants and microbesPotential source of pesticide for future use. Pesticides information, 28: 33-38.

Parameswari, C. And A. Tulasi latha. 2001. Antibacterial activity of Ricinus communis leaf extract. Indian drugs, 38: 587-588.

Patel, M. And A. Padhya. 1964. Sodium arsenite-Copper sulphate spray for the control of citrus canker. Current Science, 33: 87-88.

Rath, C., S. Dash and R. Mishra. 2001. In vitro susceptibility of Japanese mint (Mentha arvensis L.) Essential oil against five human pathogens. Indian Perfumer, 45: 57-62.

Rehman, M., N. Chaudhary and M. Nasir. 2006. Citrus canker and its control through chemicals and antibiotics under Sargodha climatic conditions. Pakistan Journal of Phytopathology, 18: 67-69.

Rossetti, V. 1977. Citrus canker in Latin America: A review. Proceedings of the International Society of Citriculture. Pp. 918-923.

Sahi, S. T., M.U. Ghazanfar,M. Afzal, A. Rashed, A. Habib. 2007. Incidence of citrus canker diseases caused by Xanathomonas campestris pv. citri (Hasse) Down on Kinnow (Citrus Reticulata) and its chemotherapy. Pakistan Journal of Botany, 39: 1319-1327.

Saleem, A. and A. H. Tariq. 1992. Important disease and their control in Punjab. Proceedings of 1st International Seminar. Citriculture in Pakistan. pp. 293-98.

Sattar, A. And A. Hafiz. 1952. Research on plant diseases of the Punjab.
Shimpi, S. And R. Bendre. 2005. Stability and antibacterial activity of aqueous extracts of Ocimum canum leaves. Indian perfumer, 49: 225.

Stall, R. E. And C. P. Seymour. 1983. Canker, a threat to citrus in the Gulf-Coast states. Plant Disease, 67: 581-585.

Sundin, G. W., D. H. Demezas and C. L. Bender. 1994. Genetic and plasmid diversity within natural populations of Pseudomonas syringae with various exposures to copper and streptomycin bactericides. Applied and Environmental Microbiology, 60: 4421-4431.

Tahir, H. A., S. T. Sahi, A. Habib, I. U. Haq, A. Ahmad and W. Ashraf. 2016. Evaluation of plant extracts as biocontrol agents against Xanthomonas axonopodis pv citri the cause of citrus canker. Pakistan Journal of Phytopathology, 28: 35-43.

Thakre, B., U. Soni, C. Gour and S. Dharpure. 2017. Effect of different chemicals for the control of citrus canker caused by Xanthomonas axonopodis pv. Citri. Plant Archives, 17: 1181-1183.

White, D. G., S. Zhao, S. Simjee, D. D. Wagner and P. F. Mcdermott. 2002. Antimicrobial resistance of foodborne pathogens. Microbes and infection, 4: 405-412.

Williams, R. J. And D. L. Heymann. 1998. Containment of antibiotic resistance. American Association for the Advancement of Science. 279: 1153-1154.

Yesmin, K., M. Ahmad, M. Momtaz and K. Begum. 2017. Effect of fungicides and plant extracts in the management of foliar, twig and fruit diseases of citrus (Citrus limon). Journal of Environmental Science and Natural Resources, 10: 93-100.

\begin{tabular}{lll} 
Contribution of Authors: & & \\
Malik A. Rehman & $:$ Designed the experiment and wrote manuscript \\
Shafqat Ali & $:$ Performed the experiment \\
Muhammad N. Khan & $:$ Analyzed the data \\
Salman Ahmad & $:$ Edit the manuscript \\
Muhmmad A. Ali & $:$ Review the manuscript \\
\hline
\end{tabular}

